\title{
GEOSPATIAL APPROACH FOR LANDSLIDE ACTIVITY ASSESSMENT AND MAPPING BASED ON VEGETATION ANOMALIES
}

\author{
Mohd Radhie Mohd Salleh ${ }^{1}$, Nurliyana Izzati Ishak ${ }^{1}$, Khamarrul Azahari Razak ${ }^{2}$, Muhammad Zulkarnain Abd Rahman ${ }^{1 *}$, Mohd \\ Asraff Asmadi ${ }^{1}$, Zamri Ismail ${ }^{1}$, Mohd Faisal Abdul Khanan ${ }^{1}$ \\ ${ }^{1}$ Faculty of Built Environment and Surveying, Universiti Teknologi Malaysia, Johor, Malaysia - mohdradhie.gis@ gmail.com \\ ${ }^{2}$ UTM Razak School of Engineering and Advanced Technology, Universiti Teknologi Malaysia, Kuala Lumpur
}

KEY WORDS: Tropical rain forest, Landslide activity, Vegetation anomalies

\begin{abstract}
:
Remote sensing has been widely used for landslide inventory mapping and monitoring. Landslide activity is one of the important parameters for landslide inventory and it can be strongly related to vegetation anomalies. Previous studies have shown that remotely sensed data can be used to obtain detailed vegetation characteristics at various scales and condition. However, only few studies of utilizing vegetation characteristics anomalies as a bio-indicator for landslide activity in tropical area. This study introduces a method that utilizes vegetation anomalies extracted using remote sensing data as a bio-indicator for landslide activity analysis and mapping. A high-density airborne LiDAR, aerial photo and satellite imagery were captured over the landslide prone area along Mesilau River in Kundasang, Sabah. Remote sensing data used in characterizing vegetation into several classes of height, density, types and structure in a tectonically active region along with vegetation indices. About 13 vegetation anomalies were derived from remotely sensed data. There were about 14 scenarios were modeled by focusing in 2 landslide depth, 3 main landslide types with 3 landslide activities by using statistical approach. All scenarios show that more than $65 \%$ of the landslides are captured within $70 \%$ of the probability model indicating high model efficiency. The predictive model rate curve also shows that more than $45 \%$ of the independent landslides can be predicted within $30 \%$ of the probability model. This study provides a better understanding of remote sensing data in extracting and characterizing vegetation anomalies induced by hillslope geomorphology processes in a tectonically active region in Malaysia.
\end{abstract}

\section{INTRODUCTION}

Landslides are the main geological hazards in many mountainous areas, where they occur regularly and rapidly at the same area in spatio-temporal way (McKean and Roering, 2004; Lee, 2007a), causing major material loss, environmental damage and loss of life. Landslide occurrences are regularly triggered by several natural phenomena, such as heavy rainfall and earthquake. A landslide will be called rainfall-induced rainfall and earthquake induced landslide, respectively, which difficult to predict unless seismic activity and rainfall distribution data are available (Glenn et al., 2006; Schulz, 2007; Haneberg, Cole and Kasali, 2009). It is essential to obtain an accurate landslide inventory analysis to make sure the accuracy of landslide susceptibility and risk analysis can be maintained (Ardizzone et al., 2007; Akgun, Dag and Bulut, 2008; Bai et al., 2010; Constantin et al., 2011; Guzzetti et al., 2012).

Landslide in Malaysia had caused huge amount of damages in terms of property, life and economic losses. It mostly affected mountainous and low stability areas due to rapid movement of soil. Due to modern development in Malaysia since 1980s, only a few low-lying and stable areas remain that are still available for residential or commercial development. This had put the life and property of people in risk of death and destruction. As a result, the development of highland or hilly terrain has increased to meet the demand for infrastructure, particularly in areas adjacent to high density cities. Such a situation has increased the probability of losses due to landslide phenomenon (Jamaludin and Hussein, 2010).

For the last decade, method of detecting landslide under forested area has been dependent on geological, geomorphological features and drainage pattern of the area
(McKean and Roering, 2004; Haneberg, Cole and Kasali, 2009; Hutchinson, 2009). Although this method would give a reliable landslide area, using tree condition as an indicator of landslide activity can lead to new methods of predicting and providing enough details about landslide activity (Harker, 1996; Razak et al., 2013; Razak et al., 2013b). Conventionally, landslide inventory mapping had undergone the process of visual interpretation based on stereoscopic images and verified with field verification. Next, image analysis by using aerial photographs, satellite and radar images had successfully emerged as it is efficiently capable in covering large areas; however, it is less accurate in mapping the landslide in forested terrain (Will and McCrink, 2002; Eeckhaut et al., 2007). This is because reflectance spectra of vegetation conceal the spectra of underlying soils and rocks and vegetation, which is the most critical barrier for geologic identification and mapping (Hede et al., 2015). This reason can be used to utilize trees in generating bio-indicators of landslide activity by recognizing local deformation and different episodes of soil displacement (Parise, 2003). However, most of the study had not focused on vegetation anomalies due to the low accuracy and density of point clouds and lack of field data validation (Razak et al., 2013). This has caused many researchers to neglect the LiDAR point clouds which represent the vegetation structures for landslide recognition (Mackey and Roering, 2011). Disrupted vegetation is often used as an indicator for landslide activity in forested region and to relate tree anomalies to landslides occurrence and its activity, the identification of disrupted trees in forested landslide is crucial (Razak et al., 2013).

Remote sensing techniques for landslides investigations have undergone rapid development over the past few decades. The possibility of acquiring $3 \mathrm{D}$ information of the terrain with high accuracy and high spatial resolution is opening new ways of 
investigating the landslide phenomena. Recent advances in sensor electronics and data treatment make these techniques more affordable. The two major remote sensing techniques that are exponentially developing in landslide investigation are interferometric synthetic aperture radar (InSAR), and LIDAR (Jaboyedoff et al., 2012). With the current remote sensing technology such as laser scanning, it had become easier for the authorities or stakeholders to determine the landslide area prior to the event. LiDAR data is currently being used for the delineation and analysis of landslide polygons that can be interpreted based on colour composite, hillshade, topographic openness or digital terrain model raster layer (Razak, 2014).

There are still lack of landslide activity analysis that rely solely on the bio-indicator that had been derived from remotely-sensed data. There are many advantages of using topographic laser scanning data in detecting and predicting landslide, i.e.; it is a very accurate technique requiring less labor needed, and the ability to cover large areas, including areas previously deemed inaccessible. In addition, it has been acknowledged for its contribution in developing and implementing forest inventory and monitoring program. This method allowed extraction of several vegetation anomalies from LiDAR data, which include tree height, abrupt change in tree height, crown width, vegetation density, different vegetation type and many more.

Previous studies have shown that the conventional method of producing landslide inventory analysis is undoubtedly time consuming, dangerous and expensive (Guzzetti et al., 2012). From this study, problems arising from implementing conventional methods can be kept to a minimum, as utilizing remote sensing technology enables the researcher to obtain vegetation anomalies as a bio-indicator of landslide activity mapping and analysis. In Malaysia, landslide analysis tends to have frequent site visit, and real-time monitoring of the deformation that can cause lots of budget to be put on, and potential hazard to property and life once the landslide struck. Thus, by using the result of this study, it can contribute to the thorough analysis of vegetation anomalies suitability as a bioindicator to landslide activity analysis. In addition, this studies also capable in defining the method to produce vegetation anomalies from remote sensing data and analyze the performance of geospatial-based approach.

This study aims in estimating and mapping different landslide type, depth and activity probability area together with producing vegetation anomaly indices along a tectonically active region, Kundasang. This was supported by several objectives as follow:

i.

To delineate and characterize landslide inventory based on different landslide type, depth and activity.

ii.

To generate vegetation properties and vegetation anomalies using high density airborne LiDAR and other remotely sensed data

iii. To generate landslide activity probability map for different landslide type and depth occurred in tectonically active region.

iv. To analyze the capability of vegetation anomalies in characterizing landslide activity for different landslide type and depth.

Vegetation anomaly maps used in generating probability maps were derived from both LiDAR and satellite image data. It is important to analyze the vegetation pattern on each landslide type, depth and activity as it gave us a new understanding about how vegetation characteristics differed from one landslide type, depth and activity to another. From the probability map, matrices for each of the scenarios has been tabulated to identify the most and the least significance vegetation anomaly characteristics in each landslide scenario. There were only a few studies conducted in Malaysia and most of the studies were using spectral reflectance to indicate the vegetation cover characteristics (Lee, 2007b; Pradhan et al., 2010; Jaewon et al., 2012). Furthermore, the output from this study can be used in future landslide susceptibility analysis as a supporting detail in characterizing landslide areas based on their current vegetation characteristics. Also, current global and national projects, for example, Sendai Framework, Slope Hazard and Risk Mapping project also known as Peta Bahaya Risiko Cerun, National Slope Master Plan etc. can fully-utilize the result from this study to suit the purpose of their projects.

\section{STUDY AREA}

\subsection{Location of study area}

The study site is located at Kundasang, Sabah, Malaysia $\left(5^{\circ} 59^{\prime} 0.69^{\prime \prime} \mathrm{N}, 116^{\circ} 34^{\prime} 43.50^{\prime \prime} \mathrm{E}\right)$, the Northern part of Sabah. Kundasang is a town located in Ranau district that lies along the bank of Kundasang Valley. As of 2010, the total population of Kundasang area is 5008 within the area of Ranau district, which is $3555.51 \mathrm{~km}^{2}$. With an elevation of about 1200 to 1600 metres above sea level, it is one of the coolest places in Sabah with temperatures dropping to $13^{\circ} \mathrm{C}$ at night (BeautifulKK, 2010; Wikitravel, 2015). Kundasang has a tropical climate. There are large amount of rainfall all year, even during the driest month (ClimateData.ORG, 2015). The average annual rainfall is \pm 2189 $\mathrm{mm}$. Figure 1 shows the study area map along debris flow area of Kundasang with focus on source zone, transport zone and deposition zone.

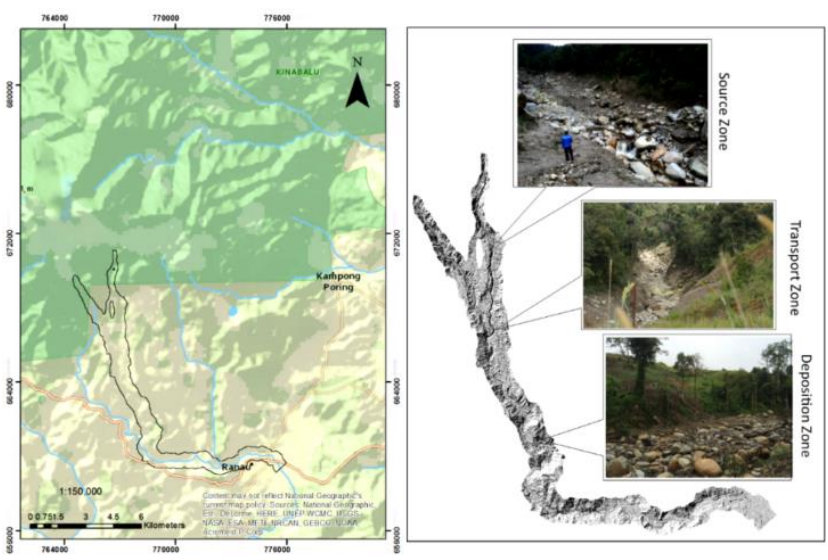

Figure 1. Location of study area at Mesilau River in Kundasang region which was struck by debris flow in June 2015

\subsection{Geological Setting of Study Area}

Kundasang region consists of three (3) types of lithology; Pinasouk gravel, Trusmadi formation and Crocker formation. On $5^{\text {th }}$ of June 2015, an earthquake measuring 6.0 Mw occurred in Sabah that had triggered the debris flow which caused the disruption of roads, houses and the vegetation along the channel (Wikipedia, 2015a). It has been recorded that the earthquake was caused by the movement on a SW-NE trending normal fault and the epicenter was near Mount Kinabalu. The shaking caused massive landslides around the mountain (Tongkul, 2015). Rocks located beneath Kundasang vary in age and type, which are the 
rock starting from Paleocene-Eocene rocks to alluvial rock. Three formations are present include Trusmadi Formation, Crocker Formation and Quaternary sediment (Tongkul, 1987). Mensaban fault zone is located on the eastern side of Kundasang area which intersects with Crocker fault. The mass movements in Kundasang area can be the result of active movement in Crocker and Mensaban fault zones.

Kundasang experiences heavy rainfall almost every month. This heavy rainfall is capable of inducing landslides as occured on $15^{\text {th }}$ and $16^{\text {th }}$ July 2013 where heavy rainfall had triggered landslides in Kampung Mesilau that killed one resident and damaged concrete bridge. Heavy rainfall on $10^{\text {th }}$ April 2011 triggered landslide in Kampung Mohiboyan and the landslide was worsened by the eroded riverbank. The landslide event damaged 19 houses and villagers were evacuated. Landslides in Kampung Pinausok were also triggered by heavy rainfall that had caused electric power outage and damaged houses. Previous study has stated that there have been more than 20 landslide occurrences from 1996 to 2015 in Kundasang (UTM PBRC, 2016). Along Mesilau River channel, at least 5 events were recorded from between year 2008 and 2015. Most of the landslides occurred due to heavy rainfall and recently the landslide occurred caused by an earthquake that happened in Sabah, which lasted for 30 seconds. The earthquake was the strongest to affect Malaysia since 1976 (The Borneo Post, 2015; United States Geological Survey, 2015; Wikipedia, 2015a). In June 2015, debris flow in Mesilau River channel (Daily Express., 2015) had seriously damaged infrastructures along the channel (Ismayatim, 2015).

\section{METHODOLOGY}

In general, the framework of the implemented methodology in this study contains five (5) main stages. The first stage concentrates on the data collection, which consists of field and remotely sensed data collection. The second stage emphasizes on the pre-processing of the collected data. The third phase focuses on delineating and characterizing landslides using remotely sensed data. In the fourth phase, the remotely sensed data was used to generate 13 vegetation anomalies indicators. The final phase focuses on data-driven modeling by generating the landslides activity maps that account different scenarios of landslide type and depth. The landslide activity maps were evaluated based on the success and prediction rate values.

\subsection{Data Collection}

The data collection phase can be divided into acquisition of remote sensing data and field data. Remote sensing data includes airborne LiDAR data, aerial photos and high-resolution of satellite images over the debris flow zone at Mesilau River. The derivatives of each data were listed as Table 1 .

\begin{tabular}{|l|rl|}
\hline \multicolumn{1}{|c|}{ Data Type } & \multicolumn{2}{|c|}{ Derivative } \\
\hline Airborne Laser Scanning & \multicolumn{2}{|c|}{ Landslide Detection Source } \\
& Data: & \\
- & 1. & Topography Openness \\
point $/ \mathrm{m}^{2} \quad \pm 160$ & 2. & Hillshade \\
on August 2015) & 3. & Colour Composite \\
& Vegetation Characteristics: \\
& 1. & Tree Height \\
& 2. & Tree Crown Gap \\
& 3. & Density of Low \\
& & Vegetation \\
& 4. & Density of Young \\
\hline
\end{tabular}

\begin{tabular}{|c|c|}
\hline & $\begin{array}{ll}\text { 5. } & \text { Woody Vegetation } \\
\text { Density of Matured } \\
\text { Woody Vegetation } \\
\text { 6. } \\
\text { Density of Old Forest } \\
\text { Vegetation }\end{array}$ \\
\hline $\begin{array}{l}\text { Satelite Images } \\
\text { Q } \\
\text { 2.4 m spatial resolution } \\
4 \text { bands: } \\
\text { Blue: } 430-545 \mathrm{~nm} \\
\text { Green: } 466-620 \mathrm{~nm} \\
\text { Red: } 590-710 \mathrm{~nm} \\
\text { Near-IR: } 715-918 \mathrm{~nm} \\
\text { - Captured } \\
\text { on 29 September } 2008\end{array}$ & $\begin{aligned} & \text { Vegetation Characteristics: } \\
& \text { 1. } \text { DVI } \\
& \text { 2. } \text { GDVI } \\
& \text { 3. } \text { GNDVI } \\
& \text { 4. } \text { NDVI } \\
& \text { 5. } \text { SAVI } \\
& \text { 6. } \text { OSAVI }\end{aligned}$ \\
\hline $\begin{array}{l}\text { Orthophoto } \\
\qquad \quad 7 \mathrm{~cm} \\
\text { spatial resolution } \\
\text { Captured } \\
\text { in August 2015) }\end{array}$ & $\begin{array}{l}\text { Landslide Detection Source } \\
\text { Data: } \\
\text { 1. } \quad \text { Landslide occurrence } \\
\quad \text { interpretation } \\
\text { Vegetation Characteristics: } \\
\text { 1. } \quad \text { Different Vegetation } \\
\text { Type Distribution }\end{array}$ \\
\hline Field Measurement & $\begin{array}{l}\text { The tree parameters are azimuth, } \\
\text { inclination, vegetation type, } \\
\text { canopy gaps, vegetation type } \\
\text { distribution, average tree height, } \\
\text { lithology, soil condition etc. }\end{array}$ \\
\hline
\end{tabular}

Table 1. A set of remote sensing data used in this study

Airborne LiDAR data was captured in August 2015, approximately two months after the debris flow that hit the Mesilau River. Figure 2 shows a visualisation of point clouds of the study area along debris flow. For this study area, there are 25 tiles with $\pm 1 \mathrm{~km}^{2}$ area for each tile, and the mean point density of the acquired data was 160 points per meter square.

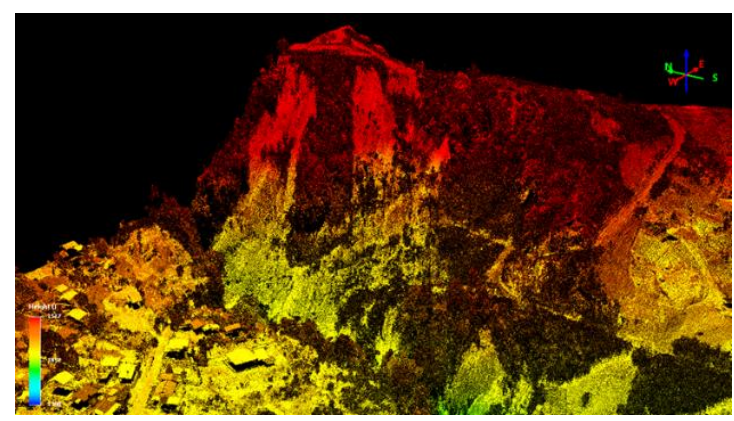

Figure 2. Close-up point clouds view of landslides area

QuickBird satelite images was used for this study. This satellite image was derived from DigitalGlobe satellite which can give up to sub-meter level for panchromatic image and $2.4 \mathrm{~m}$ spatial resolution for multispectral image. QuickBird has a stable platform for precise location measurement that allows a high geolocational accuracy. In addition, its vast view is due to its off-axis unobscured design of telescope.

Orthophoto image had been used in landslide interpretation and extraction of different vegetation type distribution. Generally, vegetation can be divided in two types based on their appearances in the aerial photographs. Natural vegetation like forests and grasslands is easy to detect due to their distinct pattern. Woody vegetation usually has dark tints indicating that 
their leaves are darker, while planted trees and agricultural crops can be identified by their straight line patterns in which they are planted (Rice University, 2016). In this study, the orthophoto used had been captured in August 2015. The area covered was along the Mesilau River channel.

The method of field measurement was carried out to collect several tree parameters. The tree parameters were valuable to enhance the understanding of vegetation differences between normal vegetation and disturbed vegetation due to landslide activities. The tree parameters are azimuth, inclination, vegetation type, canopy gaps, vegetation type distribution, average tree height, lithology, soil condition, etc. However, the field measurement will not be included in the generating probability model as it is the observation of tree characteristics to understand more about vegetation on landslide and nonlandslide areas. The parameters were collected by setting up the number of individual trees based on each location for creeping landslide and overall tree observation for rotational landslide.

\subsection{Data Pre-processing}

Pre-processing includes operations such as correction and calibration of the airborne LiDAR data. Filtering process which focus on the separation of point cloud into ground and nonground returns is the core component of LiDAR data preprocessing phase (Chen, 2007). Deriving the height of tree, building and other land features, or further analysis on the study area is only possible if the point cloud is filtered. The filtering process conducted using Adaptive TIN Densification algorithm embedded in the Terrascan software. The ground points were interpolated to generate Digital Terrain Model (DTM). Digital Surface Model (DSM) was generated by taking the highest points within $25 \mathrm{~cm}$ moving window over the entire dataset. The resulting highest points were interpolated for DSM generation with $25 \mathrm{~cm}$ spatial resolution. Canopy Height Model (CHM) was generated by subtracting DTM from DSM with 25 $\mathrm{cm}$ of spatial resolution.

\subsection{Landslide Inventory}

The landslide area was delineated based on several datasets i.e. topographic openness, hillshade, and colour composite. These datasets were generated using DTM and orthophoto. The interpretations for the landslide areas were focusing on natural terrain, agricultural terraces, and forested area.

\subsection{Estimation of Vegetation Anomalies}

Landslides are a significant cause of vegetation disturbance (Veblen and Ashton, 1978; Hupp, 1983). Based on Cruden and Varnes (1996), there were different vegetation characteristics for each landslide activity. Different landslide types can be characterized by monitoring the vegetation characteristics as stated Soeters and van Westen (1996). Vegetation anomalies for each landslides body can be used as the predictive sources of landslide analysis. It is strengthened by Van Westen (2003), who listed 5 vegetation anomalies that can be derived from landslide area which are:

1) Disordered and partly dead vegetation.

2) Disrupted vegetation cover across the slope and coinciding with morphological steps.

3) Less dense vegetated areas aligned and with lighter tones.

4) Difference in vegetation inside and outside of the landslide.

5) Change in vegetation related with drainage conditions
To view the irregularities of vegetation characteristic in the study area, two (2) main phases involved, i.e. data preparation and estimation of vegetation anomalies. Overall, 13 vegetation characteristics or anomalies were extracted from remotely sensed data which listed as follow:

1) Irregularity in tree height;

2) Tree crown gap;

3) Density of low vegetation;

4) Density of young woody vegetation;

5) Density of matured woody vegetation;

6) Density of old forest vegetation;

7) Different vegetation classes distribution;

8) Normalized Difference Vegetation Index (NDVI);

9) Difference Vegetation Index (DVI);

10) Green Difference Vegetation Index (GDVI);

11) Green Normalized Vegetation Index (GNDVI);

12) Soil Adjusted Vegetation Index (SAVI); and

13) Optimized Soil Adjusted Vegetation Index (OSAVI).

3.4.1 Irregularity in Tree Height: In this study, irregularity in tree height was calculated using standard deviation method as it show the amount of variation or dispersion of a set of data values (Bland and Altman, 1996; Wikipedia, 2017). Low standard deviation indicates that the data closed to the mean, while a high standard deviation indicates that the data points are spread out over a wider range of values. The formula of standard deviation is:

$$
\text { Standard Deviation }=\sqrt{\frac{1}{N} \sum_{i=1}^{N}\left(x_{i}-\mu\right)^{2}}
$$

where:

$x_{i}=$ Individual values, $\mu=$ Mean value

By using CHM generated from subtraction of DTM from DSM, a moving window of $3 \times 3$ was being applied to produce the irregularity of tree height. Figure 3 shows the cross section, CS(A-B) image derived from LiDAR data to provide evidence of irregularity in tree height on landslide area.

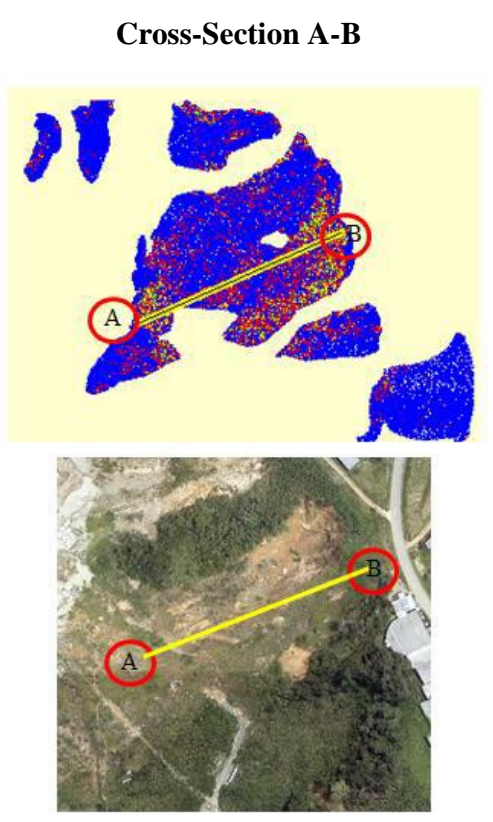




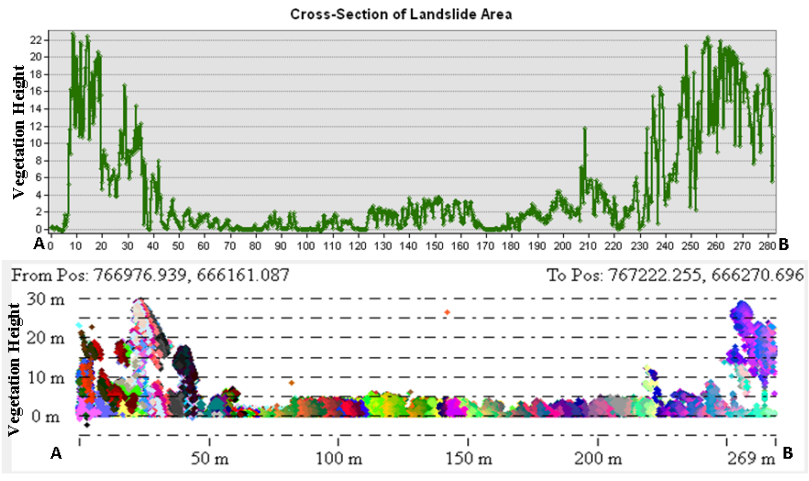

Figure 3. Irregularity in tree height on landslide area from toe (A) to crown area (B)

3.4.2 Tree Crown Gap: In this study, tree crown gap was obtained by measuring the percentage of gap beneath the canopy layer. Tree canopy layer was generated using tree crown delineation process i.e. inverse watershed segmentation, to delineate every single tree from the CHM raster layer. The delineating of individual trees will be based on cluster of height parameter (Rahman and Gorte, 2009). It is believed that the occurrence of landslide under forest can be detected by measuring the gaps of the area (Moos, 2014). Tree crown gap is proven as one of the important parameters for landslide analysis. The area with low vegetation cover or bare earth can be clearly seen with orthophoto.

3.4.3 Density of Different Layer of Vegetation: Density of the vegetation was measured using density of high points (DHP) method by Rahman and Gorte (2009). This method believed that the density of received laser pulses on a certain height is high at the center of a tree crown and decreases towards the edge of the crown. The point clouds filtering process was done by dividing the point clouds into several layers vertically. The segmented tree height was focusing on low vegetation, young woody vegetation, matured woody vegetation and old forest vegetation. The tree height classification follows the different forest developmental stages defined in the Manual for the Aerial Photo Interpretation within the Swiss Forest Inventory (Ginzler et al., 2005). This classification can be referred in Table 2 .

\begin{tabular}{|l|l|}
\hline Height & Vegetation Type \\
\hline $0 \mathrm{~m}<3 \mathrm{~m}$ & Low vegetation \\
\hline $3 \mathrm{~m}$ to $8 \mathrm{~m}$ & Young woody vegetation \\
\hline $8 \mathrm{~m}$ to $20 \mathrm{~m}$ & Matured woody vegetation / Timber \\
\hline$>20 \mathrm{~m}$ & Old forest vegetation \\
\hline
\end{tabular}

Table 2. Tree height classes (Ginzler et al., 2005).

3.4.4 Different Vegetation Type Distribution: Mapping of land use and land cover (LULC) at regional scales is essential for a wide range of applications, including landslide, erosion, land planning, global warming etc. (Reis, 2008). As stated in MS 1759:2004, documented by The Information Technology, Telecommunications and Multimedia Industry Standards Committee (2004), vegetation is listed as one of the land use and land cover features and attributes that need to be mapped. In this study, different vegetation type distribution was mapped using object-oriented approach. Using this approach, semantic image information can be gathered (Willhauck, 2000). Before LULC map can be generated, several rule-sets had to be set to enable the process of segmentation to be executed. Segmentation is the process to group the picture elements by certain criteria of homogeneity. Vegetation type in this study follows the classes provided by MS 1759:2004 which defined vegetation into 4 types: Primary Forest, Secondary Forest, Agriculture, and Shrub/Grass.

To characterize these vegetation types, several thresholds were set to differentiate one vegetation type from another. Primary forest and secondary forest were extracted automatically by fine-tuning several parameters, i.e. mean of green index, standard deviation of green index, mean of red index, mean of normalized digital surface model (nDSM) and standard deviation of nDSM. By using nDSM, degraded primary forest and secondary forest can be characterized by assigning $11 \mathrm{~m}$ above ground for primary forest and $5 \mathrm{~m}$ to $11 \mathrm{~m}$ as secondary forest. Kundasang area is assumed as degraded primary forest because of disturbances and development on the surrounding areas. Other green objects were classified into combination of Shrub/Grass and Agriculture, which then reclassified manually using visual inspection of $7 \mathrm{~cm}$ orthophoto into separate classes.

Merging process of manual digitized features with automatic delineated features from object-based image analysis produced topological errors in terms of overlapping features. Millions of errors resembling of overlapping features require computational-intensive cleaning from conventional GIS approach of topological fixing. Alternative of using objectbased approach significantly reduces time taken by retaining the actual accuracy of LULC for susceptibility and hazard modeling purposes.

3.4.5 Vegetation Index: Vegetation indices are mathematical transformations designed to assess the spectral contribution of vegetation to multispectral observations. Usually the bands used are Green, Red and Near Infrared (NIR). These vegetation indices operate by contrasting intense chlorophyll pigment absorptions in the red against the high reflectivity of plant materials in the NIR (Tucker J., 1979; Elvidge D. and Chen, 1995). As one of the criteria in landslide area is low presence vegetation (Soeters and van Westen, 1996), it is essential that anomalies be analyze in this study. There are six vegetation indices derived from Quickbird of $2.40 \mathrm{~m}$ spatial resolution. These vegetation indices as stated in Table 3:

\begin{tabular}{|l|l|}
\hline $\begin{array}{l}\text { Vegetation } \\
\text { indices }\end{array}$ & Description \\
\hline $\begin{array}{l}\text { Normalized } \\
\text { Vegerence } \\
\text { (NDVI) }\end{array}$ & $\begin{array}{l}\text { No green leaves give a value close to zero } \\
\text { and close to positive 1 (0.8 - 0.9) } \\
\text { indicates the highest possible density of } \\
\text { green leaves. Low value of NDVI is } \\
\text { usually related to the frequency of the } \\
\text { landslide occurrence as it shows low } \\
\text { vegetation cover (Lina, Lin and Chou, } \\
\text { 2006). }\end{array}$ \\
\hline $\begin{array}{l}\text { Difference } \\
\text { Vegetation Index }\end{array}$ & $\begin{array}{l}\text { DVI is a method primarily sensitive to the } \\
\text { green leaf material or photosynthetically } \\
\text { active biomass present in the plant } \\
\text { canopy (Tucker J., 1979). High value of } \\
\text { difference vegetation index will indicate } \\
\text { low landslide activity in that area. }\end{array}$ \\
\hline $\begin{array}{l}\text { Green Difference } \\
\text { Vegetation Index } \\
\text { (GDVI) }\end{array}$ & $\begin{array}{l}\text { GDVI is originally designed with colour- } \\
\text { infrared photography to predict nitrogen } \\
\text { requirements for corn (Sripada et al., } \\
\text { 2006). }\end{array}$ \\
\hline $\begin{array}{l}\text { Green } \\
\text { Normalized }\end{array}$ & $\begin{array}{l}\text { GNDVI is an index of plant "greenness" } \\
\text { or photosynthetic activity and is one of }\end{array}$ \\
\hline
\end{tabular}




\begin{tabular}{|l|l|}
\hline $\begin{array}{l}\text { Vegetation Index } \\
\text { (GNDVI) }\end{array}$ & $\begin{array}{l}\text { the most commonly used vegetation } \\
\text { indices to determine water and nitrogen } \\
\text { uptake into the crop canopy. }\end{array}$ \\
\hline $\begin{array}{l}\text { Soil Adjusted } \\
\text { (SAVI) }\end{array}$ & $\begin{array}{l}\text { It uses a canopy background adjustment } \\
\text { factor, L, which is a function of } \\
\text { vegetation density and often requires } \\
\text { prior knowledge of vegetation amounts. } \\
\text { This index is best used in areas with } \\
\text { relatively sparse vegetation where soil is } \\
\text { visible through the canopy (Huete, 1988), } \\
\text { coinciding with fact that landslide is often } \\
\text { associated with bare soil conditions that } \\
\text { are located amongst vegetation area. }\end{array}$ \\
\hline $\begin{array}{l}\text { Optimized Soil } \\
\text { Adjusted } \\
\text { Vegetation Index } \\
\text { (OSAVI) }\end{array}$ & $\begin{array}{l}\text { It uses a standard value of 0.16 for the } \\
\text { canopy background adjustment factor. } \\
\text { This value provides greater soil variation } \\
\text { than SAVI for low vegetation cover, } \\
\text { while demonstrating increased sensitivity } \\
\text { to vegetation cover greater than 50\%. } \\
\text { Thus, this index is best used in areas with } \\
\text { relatively sparse vegetation where soil is } \\
\text { visible through the canopy (Rondeaux, } \\
\text { Steven and Baret, 1996). }\end{array}$ \\
\hline
\end{tabular}

Table 3. Description of vegetation indices derived from satelite imageries

\subsection{Determination of Landslide Activity Probability Map}

To produce landslide activity probability map, bivariate approach was applied. The bivariate approach used Hazard Index formula by inputting specific number of factor maps and preferably executes selected landslide type and activity. To produce various numbers of maps based on different landslide activity, type and depth, repetitive steps performed. The output map layer has been evaluated by using success rate and predicted rate. The fact that this concept utilizes a significant number of factor maps means several weights were generated. These distinctive weights were finally combined and produced vegetation anomalies indices. Equation 2 used in conducting the process:

$$
W i=\ln \left(\frac{\text { DenClass }}{\text { DenMap }}\right)=\ln \left(\frac{\frac{\text { Area }(\mathrm{Si})}{\text { Area }(\mathrm{Ni})}}{\frac{\text { Area }(\mathrm{Si})}{\text { Area }(\mathrm{Ni})}}\right.
$$

where,

$W i=$ the weight given to a certain factor class

Densclas $=$ the landslide density within the factor class Densmap $=$ the landslide density within the factor map Area $(\mathrm{Si})=$ area that contain landslides in a certain factor class Area $(\mathrm{Ni})=$ the total area in a certain factor class

\subsection{Vegetation Anomalies Indices}

Generating vegetation anomalies indices required 13 layers of vegetation anomalies together with different landslide activities, types and depth to be evaluated. These layers will be ranked based on their importance in the landslide occurrences. The importance of the vegetation anomalies will be sort based on their weight generated from Hazard Index model. The importance value is then being measured using Pairwise comparison. Pairwise comparison generally is a process of comparing entities in pairs to judge which of each entity is preferred, or has a greater amount of some quantitative property, or whether or not the two entities are identical (Wikipedia, 2015b). Pairwise comparison is a kind of divideand-conquer problem-solving method. It allows one to determine the relative order (ranking) of a group of items. This is often used as part of a process of assigning weights to criteria in design concept development (Filippo, 2005). By using pairwise comparison, the output will be in the form of percentage of importance.

\section{RESULTS AND DISCUSSION}

\subsection{Field Observation of Landslide Area}

Site visit was done to make sure of the presence of vegetation anomalies on the landslide area. This procedure was done using the finalized version of landslide inventory for rotational landslides, and for creep landslide, it was recommended by the geologist expert as it is outside of the study. Although it is outside of the study area, based on the geologist expert, it is interesting to study about creeping landslide as it is highly correlated with the fault-line as evidenced by the slanted trees. Therefore, the analysis of this subtopic will be divided into two parts, which is rotational slide and creeping landslide. The final output of this stage will be used as one of the recommendations for the mitigation procedure.

4.1.1 Creep Landslide: Figure 4 shows the rose diagram for trees measured at the TM Resorts, Kundasang. The diagram shows that most of the trees are oriented towards $10^{\circ}$ to $30^{\circ}$ from the North. The direction of the movement has been analyzed with the nearby active fault. The direction of inclined trees was parallel with the direction of the strike-slip fault.

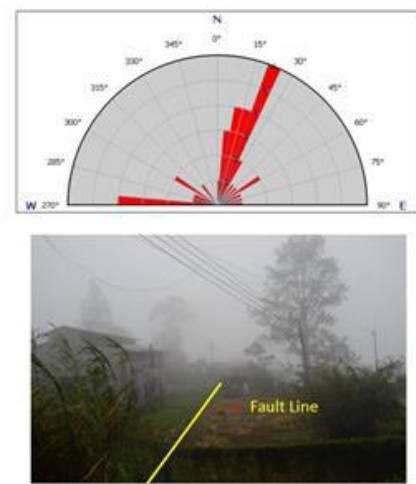

(a)

Figure 4. Rose Diagram of inclined trees found at TM Resort creeping landslide (a) that are parallel to the direction of nearby fault line (b)

From the histogram of the tree inclination angle at the TM Resort plot, it shows that the inclination angle ranges between $63^{\circ}$ and $90^{\circ}$ (Figure 5). Inclination angle is the angle of tree trunk from the ground, in which the ground is set as $0^{\circ}$. The plot was mostly covered by matured trees and small $\left(37^{\circ}\right.$ to $\left.10^{\circ}\right)$ inclination angles reflect the speed of movement of the area. The surrounding area still accommodates buildings and other facilities. The road maintenance was still manageable due the nature slow movement of the creep slides. 


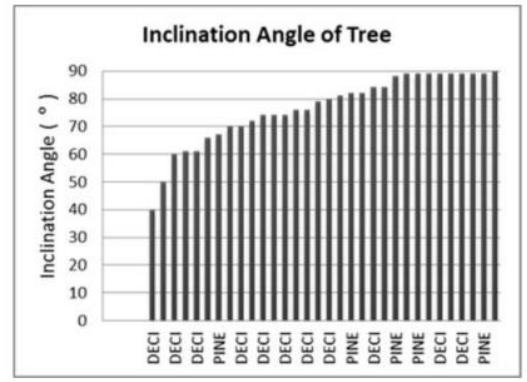

Figure 5. Histogram of inclination angle at TM Resort creeping landslide

Based on Figure 6, it can be seen that most of the trees in TM Resort plot are inclined between $80^{\circ}$ and $90^{\circ}$ with the percentage value of $76 \%$. Only $24 \%$ of the total trees were classified the second group with $63^{\circ}$ to $79^{\circ}$ of inclination from the ground.

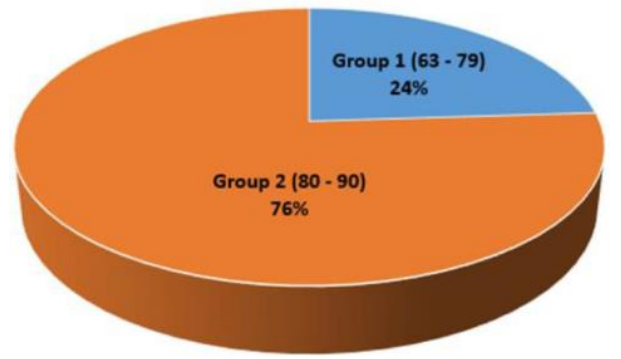

Figure 6. Percentage of trees according to the inclination angle at the TM Resorts

Figure 7 shows the percentage of trees according to their DBH values. The slow movement of slides in this area clearly allows mature trees to grow. The data shows that $42 \%$ of the trees at the TM Resort area were trees with $30 \mathrm{~cm}$ to $50 \mathrm{~cm} \mathrm{DBH}$. The percentage of trees with DBH below $30 \mathrm{~cm}$ and above $50 \mathrm{~cm}$ was $26 \%$ and $32 \%$, respectively. The slow movement of the creep landslides has clearly allowed the growth of the matured trees.

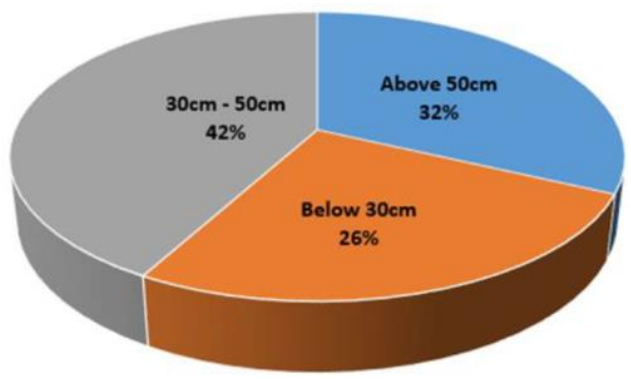

Figure 7. Percentage of trees according to the DBH measurement of trees at the TM Resort

Plot at the Celyn Resort was covered by small trees. Several landslide mitigation measures have been taken to reduce the impact of movement on the buildings of the resort. The field observation has found several pieces of evidence of the past movements and some of them have been strengthened by constructing gabion wall and proper water outlets. Figure 8 shows the orientation or direction of the trees at the Celyn Resort, which ranges between $315^{\circ}$ and $355^{\circ}$ from North. The direction of movement as obtained from trees was parallel with the past movements observed in the field.

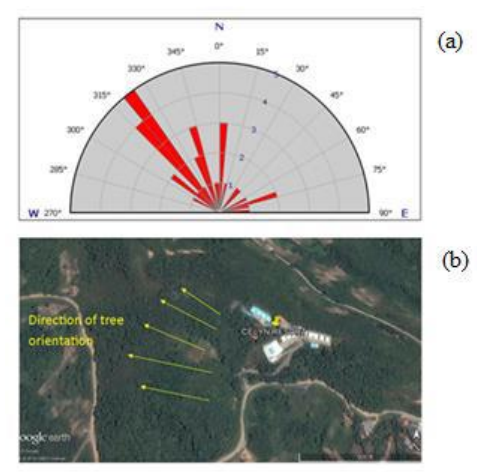

Figure 8. Rose diagram of Celyn Resort creeping landslide (a) and the past movements as observed in the field (b)

The inclination angle for trees at the Celyn Resort ranges between $40^{\circ}$ and $90^{\circ}$ from the ground (Figure 9). The range is bigger than trees at the TM resort, which were more consistent inclination angles.

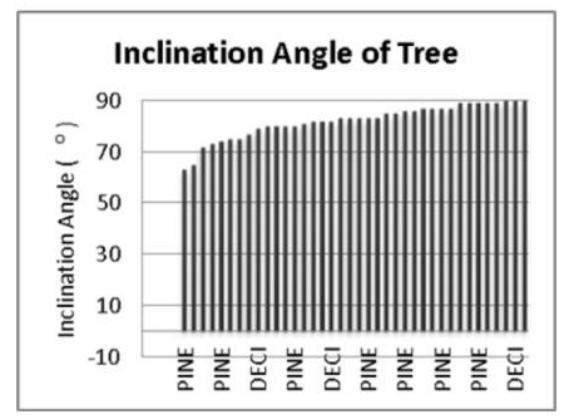

Figure 9. Histogram graph of inclination angle in Celyn Resort plot

Figure 10 shows the trees at the Celyn Resort and the pie chart indicates there was good balance between trees with $80^{\circ}$ to $90^{\circ}$ inclination angles and below $80^{\circ}$ from the ground surface. Only $6 \%$ of the total trees marked obvious inclination between $40^{\circ}$ and $60^{\circ}$. The trees in this plot were well maintained and the inclination process of the trees might be controlled by effective landslide mitigation measures in downslope areas.

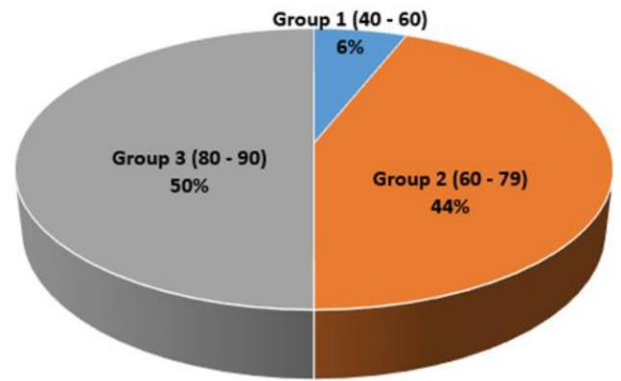

Figure 10. Percentage of trees according to the inclination angle at the Celyn Resort

Trees at the Celyn Resort vary with age with $38 \%, 34 \%$ and $28 \%$ of the trees classified under $20-30 \mathrm{~cm}, 10-19 \mathrm{~cm}$ and 20 $35 \mathrm{~cm}$ of DBH, respectively (Figure 11 ). About $38 \%$ of the trees $\mathrm{DBH}$ at the Celyn Resort plot were measured from small trees with DBH below than $10 \mathrm{~cm}$. Furthermore, since Celyn Resort management team has strong landslide hazards awareness, they continuously plant trees to reduce the impact of landslides. 


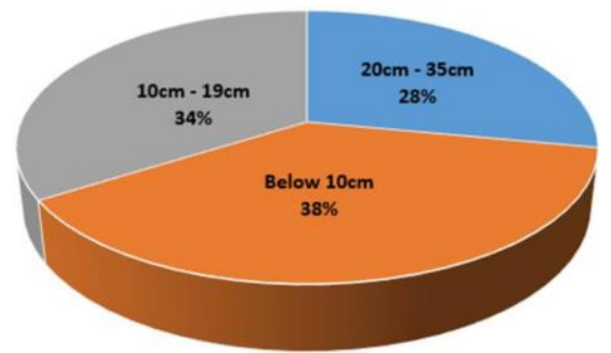

Figure 11. Percentage of trees according to the DBH measurement of trees at the Celyn Resort

4.1.2 Rotational Landslide: Each plot for rotational landslides consists of several units of landslides (Figure 12 and Figure 13). Figure 12 shows the scarp areas on the left side covered by dense shrubs (Napier grass) with height between $3 \mathrm{~m}$ and $4 \mathrm{~m}$. The landslide body was covered by dense woody plants with height ranged between $18 \mathrm{~m}$ and $30 \mathrm{~m}$ and characterized by relatively dense canopy cover. This area is a dormant landslide area with stable soil condition mostly covered by huge trees.

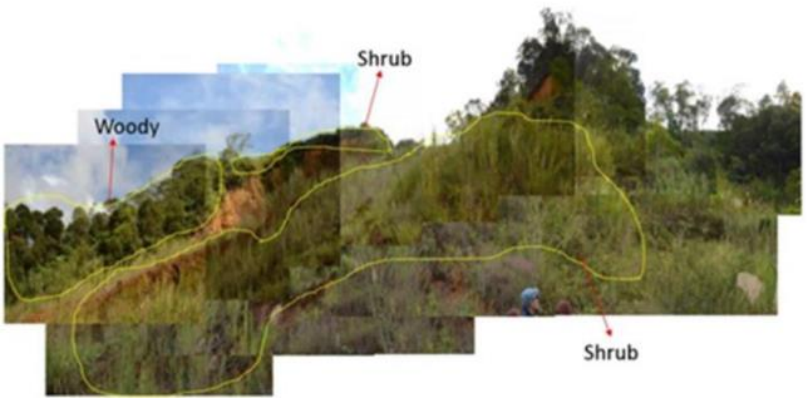

Figure 12. Plot 1 landside multi-photo vertical profiling

On the right side of the plot, the terrain of the landslide body is mostly covered by Napier grass/shrub. The soil is spongy and damp, which is suitable for Napier grass to grow (Henderson and Preston, 1977; Orodho, 2006). This plot is classified as an active landslide area with clear evidence of fresh cracks on the terrain. The terrain condition of this area is totally different compared to the right-side area with more stable terrain condition. Figure 13 shows 6 landslide polygon located in Plot 2 of rotational slide.

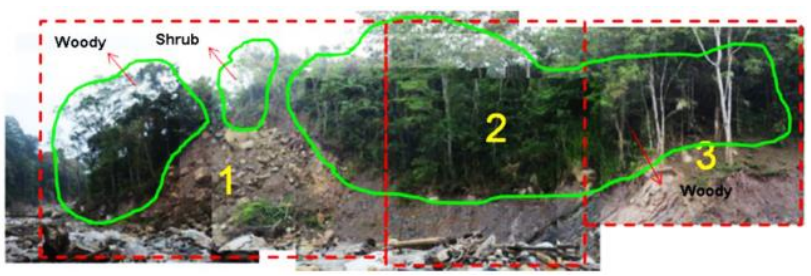

(i)

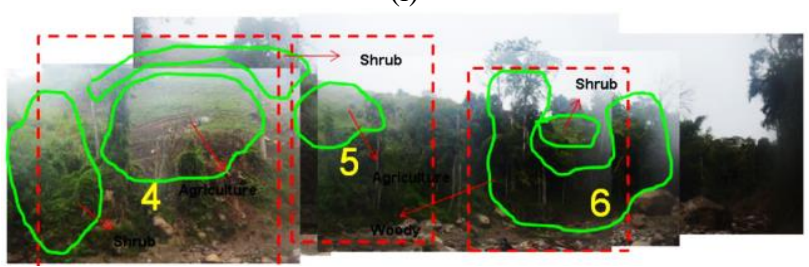

(ii)

Figure 13. Landslide profiling on 6 landslide polygons (green color) and its delineation based on different type of vegetation
The plot is characterized by Pinosouk gravel lithology type, which is comprised of large boulders, stone and sand. The scarp area for landslide 1 was mainly covered by shrubs and slowly replaced by woody trees (with height ranged between $14 \mathrm{~m}$ and $28 \mathrm{~m}$ ) and dense understory vegetation in a stable landslide body (dormant) on the left side. This aligns with the finding that there is strong contrast between mobilized zones (with a loss of vegetation cover) and non-mobilized zones (that conserve the vegetation cover) (Fernández et al., 2008). The right side of the landslide body showed a fresh evidence of the new landslide or reactivation of the old landslide. The shrub was mainly dominated by Napier grass, which indicates high water content in the underneath soil (Henderson and Preston, 1977; Orodho, 2006).

Landslide 2 consists of mature woody trees and understory vegetation growing on a stable terrain of a dormant landslide unit. There were also several slanted trees, which might also indicate that the terrain is still slowly moving downwards. It is strengthening by the fact that trees with curved trunks due to soil creep may provide a useful indication of slope instability (Harker, 1996; Razak et al., 2013a; Razak et al., 2013b). The lower part of landslide 3 was mainly covered by matured trees and understory vegetation. There was also a clear sign of erosion in the steep side of the area that might trigger new landslides in future. The upper side of landslide 3 has been utilized for agricultural activities. The landslide body for unit 4 was mainly used for agricultural proposes (Figure 15), which indicates fertile and stable terrain condition with terraces. Due to intensive irrigation activities in the upslope area, this might trigger reactivation or new landslide on right side and the growth of dense shrubs on the left side of the downslope area. The presence of water can permeate into the soil or rock. Therefore, it will replace the air in the pore space or fractures since water is heavier than air. Hence, water filling the gap will increase the weight of the soil. Weight is force, and force is stress divided by area, so the stress increases and this can lead to slope instability (Watkins and Hughes, 2004; Ritter and Eng, 2012). The scarp area of landslide 4 was mainly occupied by shrub.

For landslide unit 5, the landslide body was occupied for agricultural purposes and slowly replaced by shrubs and woody trees in the landslide toe. The landslide was classified as dormant but the agricultural purposes might trigger new landslide in future. The excessive irrigation activity might cause dense understory vegetation in the lower part of the landslide unit. The body of landslide unit 6 was covered by shrub and matured woody vegetation in the toe area. The landslide was classified as dormant. The shrub area on the body of the landslide might be the sign of unstable terrain of this area. The rainfall and excessive irrigation activities in the plot have revealed few spots of ground water flow as shown in Figure 14. 


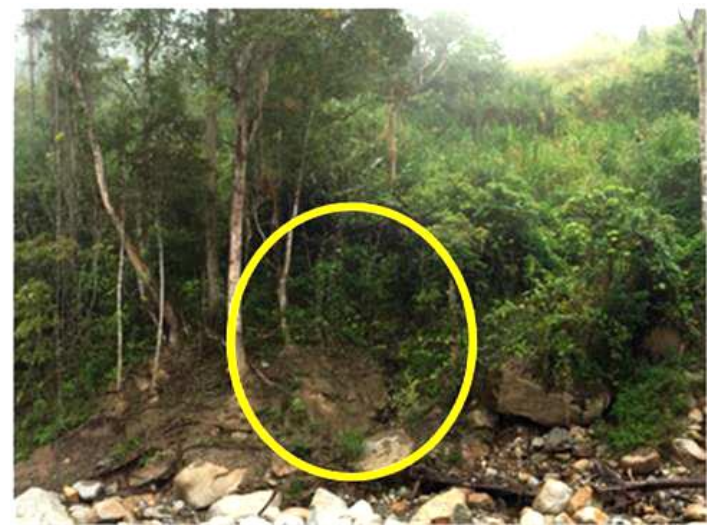

Figure 14. Evidence of groundwater flow marked by the yellow circle

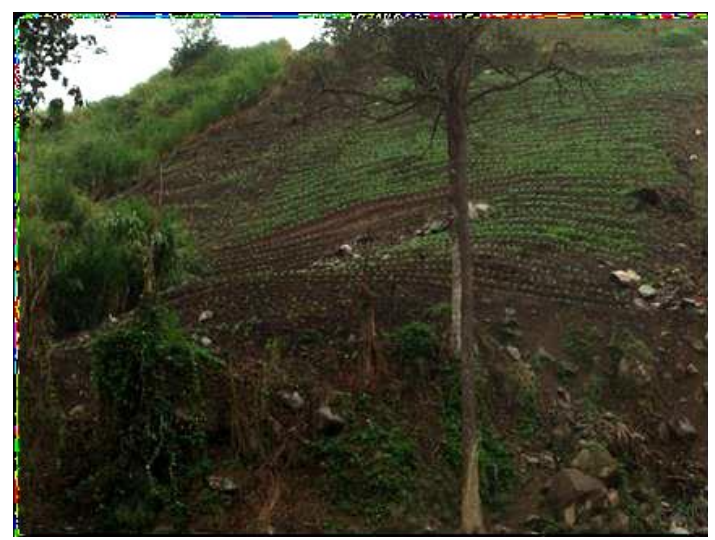

Figure 15. Landslide body been used as agricultural area

The results have clearly showed that the physical condition of the terrain classified as landslides has strong relationship with the vegetation type and its unique characteristics. The presence of Napier grass indicates high water content in the soil. Shrub generally dominates the unstable terrain, in which it is difficult for woody vegetation grow. Dense matured woody vegetation is normally found in a stable area that allows the trees to grow for a considerable period of time. However, slanted trees might indicate reactivation of the landslides in this area. Slanted trees, also known as drunken trees, were mainly found in creep type of landslide.

\subsection{Landslide Activity Probability Based on Different Depth and Type}

The procedure of obtaining the probability map was derived from statistical analysis of bivariate approach. This method was proven as one of the promising methods to produce probability map. The generated probability map was evaluated by using success rate and prediction rate (Van Westen, 2008). The success rate procedure was carried out to know how well the model performs and prediction rate used to determine how well the model can be used as a prediction model. Both evaluation methods were carried out by using $70 \%$ and $30 \%$ from total number of landslide scenarios for success rate and prediction rate, respectively.

Figure 16 shows the active landslides probability map. This probability map was generated using all the landslides with active state of activity without categorized based on their depth and type. The output from this scenario shows a high probability of active landslide at the initial state of transport zone. This location is where the landslides (Figure 17) had caused severe road damage.

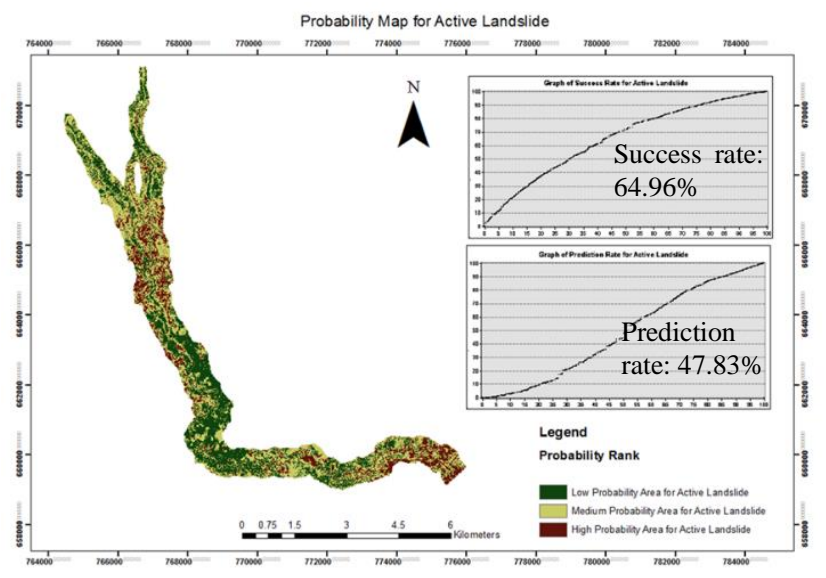

Figure 16. Probability map of active landslide

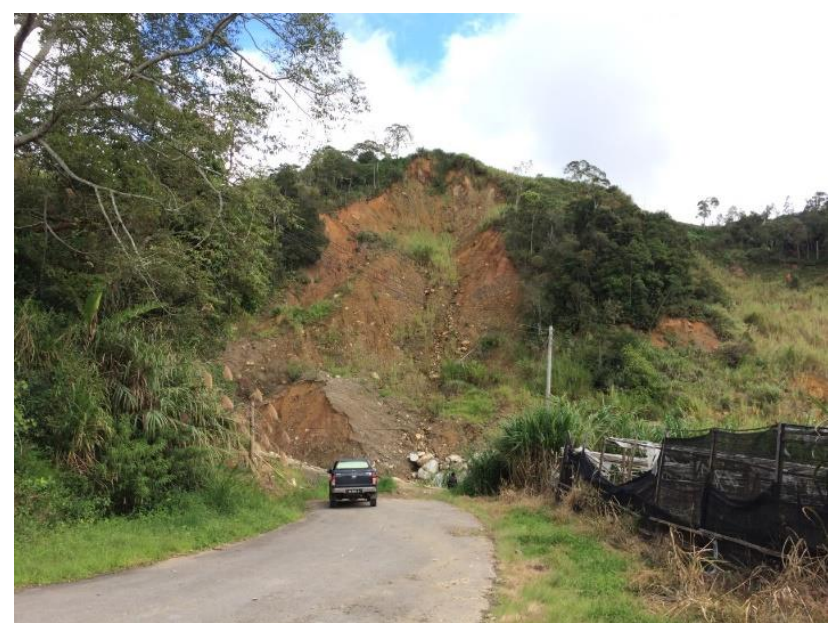

Figure 17. Active rotational landslide on the Mesilau riverbank

From the field observation of the landslides, it seems that the soil of the landslide is constantly moving and induced the landslide area to expand from time to time. The probability map of middle area of transport zone of debris flow in Mesilau River area shows low probability of the occurrence of active landslides.

Probability map of dormant landslides (Figure 18) shows a contradictory result from the active landslide map. The high probability for dormant landslides to occur was located at the middle of transport zone until the initial part of deposition zone. Transport zone of the study area seems to have large number of dormant landslides of significant size compared to active landslide. Deposition zone is where Ranau area is located which dominated by residential, government and commercial buildings. Source zone of the study area also considered as high probability of the dormant landslide. 


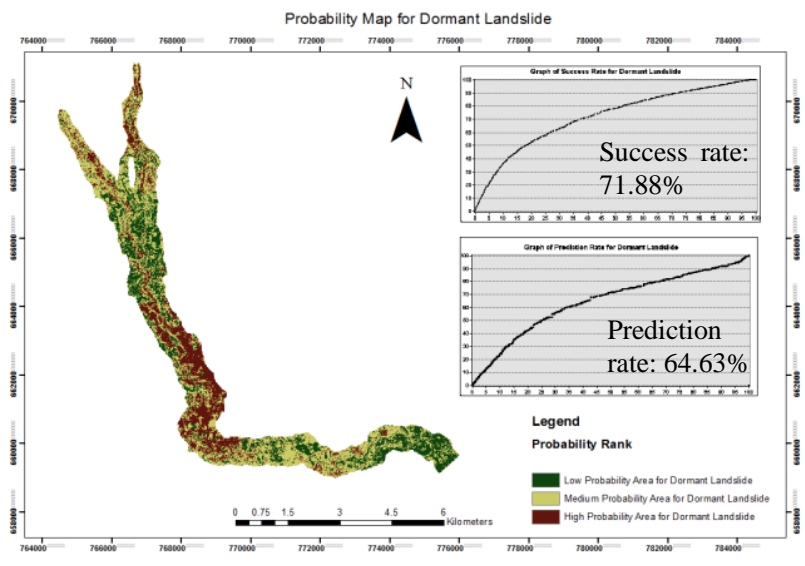

Figure 18. Probability map of dormant landslide

Figure 19 shows the probability map for the relict landslides. There were only 19 landslide polygons detected with relict state of activity along the study area. Thus, this makes the result incomprehensive and focuses only on areas with landslides. The map shows that most of the study area was covered with high probability of relict landslides except at the initial part of transport zone. This area mainly categorized by active landslide area.

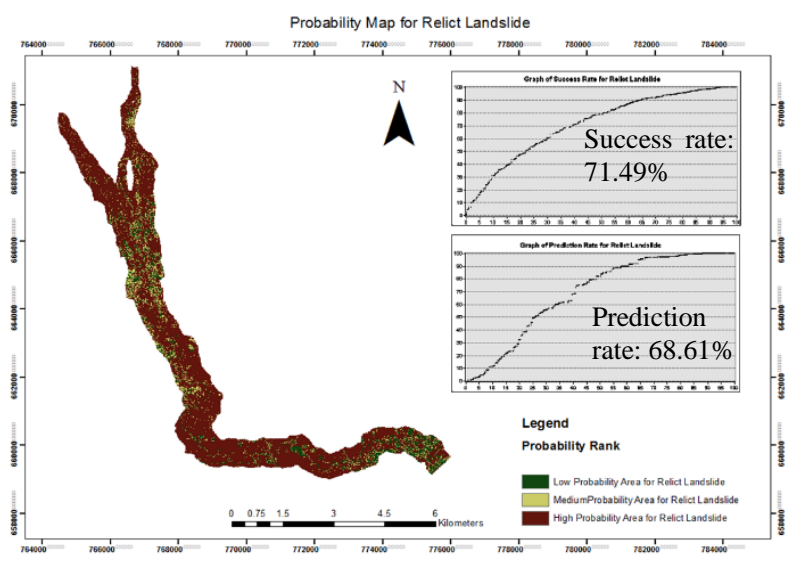

Figure 19. Probability map of relict landslide

The landslide probability map based on different type and state of activity also were derived using bivariate approach.

\section{Deep-seated}

Deep-seated active landslide probability map shows the similar pattern as the probability map for active landslides especially for high probability category, however the medium and low probability shows a slightly different pattern. The pattern of deep-seated dormant probability map shows similar pattern as the dormant probability map, however the number of pixels for high probability were slightly decreased as the number of pixel for low probability for deep-seated dormant increased. The probability map for deep-seated relict landslide shows a mixture of both high and low probability at source zone and initial part of transport zone.

\section{Shallow}

In case of shallow active probability map, low probability at the source zone and high probability at the initial part of transport zone were identified. The remaining transport zone shows a low probability of shallow active as the area densely occupied with vegetation, therefore low opportunity for active landslides to be occured. Probability map for shallow relict dominantly classified as medium probability to occur. The corner of the transport zone shows high probability of the shallow relict to occur where this area is fully covered by well-grown woody vegetation (Figure 20). This is because the inactive state of landslide will enable the vegetation to grow or re-vegetate.

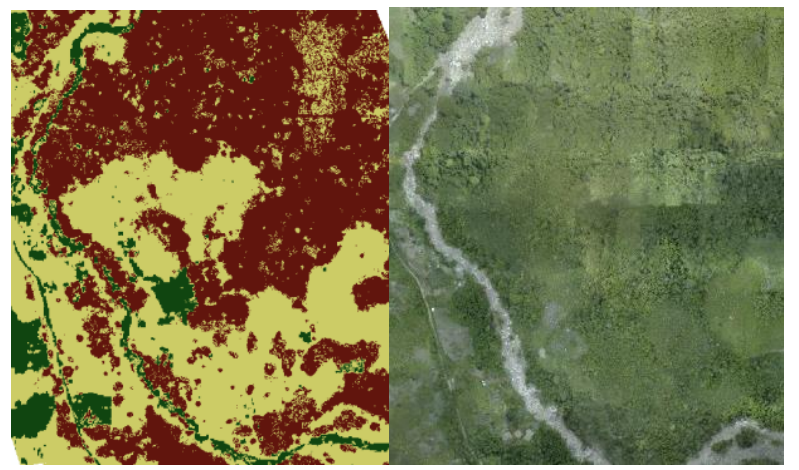

Figure 20. High probability of shallow relict landslide and orthophoto of the area

\section{Rotational}

Most of the study area was covered with medium probability of rotational active, except at the middle of transport zone, which shows high probability for rotational active to occur. The probability map generated based on rotational active does not show a clear pattern as the location of rotational active is only located in the middle of transport zone. Probability map for rotational dormant landslides shows a clearer pattern compared to rotational active, as the number of landslides were 4 times more compared to the rotational active map. Most of the area at source zone shows high probability of rotational dormant, while the transport zone shows low probability of dormant landslides since most of the active landslides were located. Transport zone was covered with low vegetation, whereas the high probability of rotational dormant was located within the tall vegetation as shown in Figure 21.
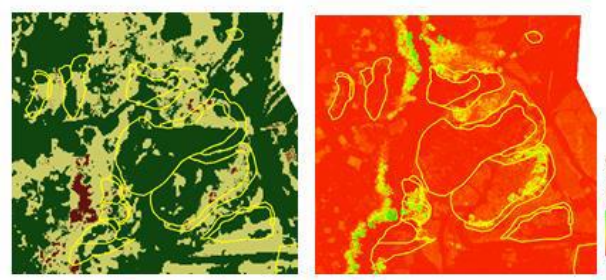

$\mathrm{CHM}$ Height (m)

(a)
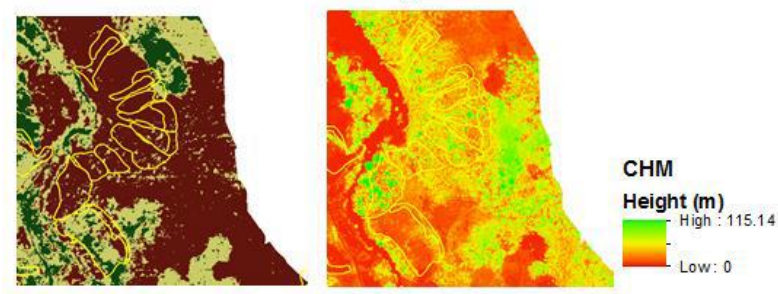

(b)

Figure 21. Landslide polygons located within (a) low probability of rotational dormant (b) high probability of rotational dormant 


\section{Translational}

Probability map for translational dormant landslides shows similar pattern with the translational dormant in which the high probability of translational dormant located in the middle of transport zone. The source zone area was classified as high probability of translational relict while the middle transport zone still shows high probability for translational relict, same as translational dormant probability map.

\section{Complex}

Most of the area was classified as low probability for complex landslides to occur except at the initial part of transport zone. This is because complex landslide seldom occurs because a combination of two or more of the landslide types is required (USGS, 2004).

From the generated maps, success rate and prediction rate have been calculated based on the listed landslide scenarios. The success and prediction rate of the scenarios were shown in Table 4:

\begin{tabular}{|l|l|c|c|}
\hline $\begin{array}{c}\text { Landslide } \\
\text { Type and } \\
\text { Process }\end{array}$ & $\begin{array}{c}\text { Landslide } \\
\text { Activity }\end{array}$ & $\begin{array}{c}\text { Success } \\
\text { Rate (\%) }\end{array}$ & $\begin{array}{c}\text { Prediction } \\
\text { Rate (\%) }\end{array}$ \\
\hline \multirow{2}{*}{$\begin{array}{c}\text { All type of } \\
\text { landslide }\end{array}$} & Active & 64.96 & 47.83 \\
\cline { 2 - 4 } & Dormant & 71.88 & 64.63 \\
\cline { 2 - 4 } Deep-seated & Relict & 71.49 & 68.61 \\
\cline { 2 - 4 } & Active & 75.48 & 28.77 \\
\cline { 2 - 4 } & Dormant & 76.15 & 69.74 \\
\hline \multirow{3}{*}{ Shallow } & Relict & 81.43 & $\begin{array}{c}\text { Not } \\
\text { Available }\end{array}$ \\
\cline { 2 - 4 } & Dotive & 72.7 & 47.34 \\
\cline { 2 - 4 } & Relict & 71.93 & 54.75 \\
\hline \multirow{2}{*}{ Rotational } & Active & 71.45 & 83.04 \\
\cline { 2 - 4 } & Dormant & 69.05 & 85.55 \\
\hline \multirow{2}{*}{ Translational } & Dormant & 77.65 & 70.6 \\
\cline { 2 - 4 } & Relict & 84.44 & $\begin{array}{c}\text { Not } \\
\text { Available }\end{array}$ \\
\hline \multirow{2}{*}{ Complex } & Active & 77.32 & $\begin{array}{c}\text { Not } \\
\text { Available }\end{array}$ \\
\hline
\end{tabular}

Table 4. Success rate and prediction of the 14 scenarios

Table 4 shows the success rate and prediction rate for each landslides probability map scenario. There were 14 success rates generated from the probability map, however only 11 prediction rates were successfully executed due to the other three scenarios consist of low landslides polygon. The highest value of success rate was the translational relict landslides with $84.44 \%$. Meanwhile, active landslide recorded the lowest success rate value with $64.96 \%$. In case of prediction rate, the highest value obtained from rotational dormant landslide with $81.92 \%$, while deep-seated active landslide recorded the lowest prediction rate value with $28.77 \%$. Overall, the prediction rate value was ranged from $55 \%$ to $70 \%$.

\subsection{Vegetation Anomalies Indices}

Weight obtained from the statistically bivariate approach had been extracted manually. The weight listed was based on classified vegetation anomalies raster layer that were derived from satelite images and airborne LiDAR. Then, the weight has been sort according to the weightage value from highest to the lowest. After the sorting phase, pairwise comparison has been done by comparing the factor maps. The comparison tables are based on their data source; LiDAR and satellite image. After the process of comparing each of the raster layers, the percentage of importance for each vegetation anomaly were obtained. As vegetation can easily hide the slide condition, especially the dormant and relict landslides, it is important to know which vegetation anomalies can be used as a bio-indicator in landslide analysis. Table 5 shows the vegetation anomalies index for all landslide activities (i.e. active, dormant, and relict)

\begin{tabular}{|l|c|c|c|}
\hline \multirow{2}{*}{ Vegetation Anomalies } & \multicolumn{3}{|c|}{ Percentage of importance (\%) } \\
\cline { 2 - 4 } & Active & Dormant & Relict \\
\hline \multicolumn{3}{|c|}{} \\
\hline Canopy Gap & 19 & 9.52 & 23.8 \\
\hline Density of Shrub & 23.8 & 4.76 & 9.52 \\
\hline $\begin{array}{l}\text { Density of Young Woody } \\
\text { Vegetation }\end{array}$ & 9.52 & 19 & 0 \\
\hline $\begin{array}{l}\text { Density of Mature Woody } \\
\text { Vegetation }\end{array}$ & 14.3 & 23.8 & 14.3 \\
\hline Density of Old Forest & 0 & 28.6 & 4.76 \\
\hline $\begin{array}{l}\text { Irregularity in Vegetation } \\
\text { Height }\end{array}$ & 4.76 & 0 & 28.6 \\
\hline $\begin{array}{l}\text { Vegetation Type } \\
\text { Distribution }\end{array}$ & 28.6 & 14.3 & 19 \\
\hline \multicolumn{4}{|c|}{ Satelite Image-derived } \\
\hline DVI & 0 & 20 & 26.7 \\
\hline GDVI & 6.67 & 26.7 & 33.3 \\
\hline GNDVI & 13.3 & 33.3 & 20 \\
\hline NDVI & 33.3 & 0 & 6.67 \\
\hline OSAVI & 26.7 & 13.3 & 0 \\
\hline SAVI & 20 & 6.67 & 13.3 \\
\hline
\end{tabular}

Table 5. Vegetation anomalies index in percentage for all landslide activities

Table 5 indicates that vegetation type distribution map is the most important index with $28.6 \%$ index value for active landslides. The type of vegetation that highly is grass type while the least important vegetation anomalies are the density of old forest vegetation. This is because it is impossible to have old forest vegetation on a moving landslide body and scarp. For satellite image-derived data, NDVI with negative values to 0.1 give the highest percentage with $33.3 \%$. This NDVI value indicates very low presence of vegetation and ground. For dormant landslides, the highest percentage is the density of old forest. Forest can grow very well due to stable soil condition. Next, the second most important indicator is medium and high density of mature woody vegetation. This type of vegetation always located among the old forest vegetation as shown in Figure 22. GNDVI shows the highest percentage of the data derived from satellite image. This is because woody vegetation takes up more water content compared to grass vegetation on active landslides (Chan et al., 2013). Irregularity in tree height is the most important indicator of recognizing relict landslides. Relict landslides normally occupied with a very dense vegetation cover (Wong et al., 2004) with different growth rate. GDVI shows the highest important value for category of satellite imagery derived data.

Vegetation index values based on different type and depth of landslides also were calculated. The percentage of importance value was separated into two categories i.e. LiDAR-derived and satelite image-derived. Table 6 shows the index value of active landslide activity categorized by landslide types. 


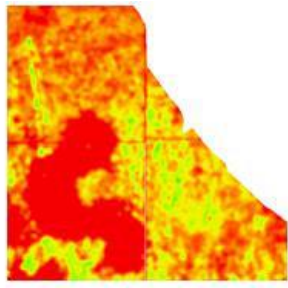

(a)

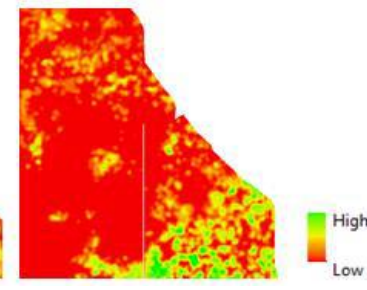

(b)
Figure 22. High density mature woody vegetation (a) located in the same area of high density of old forest vegetation (b)

\begin{tabular}{|l|c|c|c|c|c|}
\hline \multirow{2}{*}{$\begin{array}{c}\text { Vegetation } \\
\text { Anomalies }\end{array}$} & \multicolumn{5}{c|}{ Percentage of importance (\%) } \\
\cline { 2 - 6 } & DS & S & R & T & C \\
\hline Canopy Gap & 23.8 & 19 & 23.8 & - & 23.8 \\
\hline Density of Shrub & 19 & 23.8 & 28.6 & - & 19 \\
\hline $\begin{array}{l}\text { Density of Young } \\
\text { Woody Vegetation }\end{array}$ & 14.3 & 0 & 9.52 & - & 9.52 \\
\hline $\begin{array}{l}\text { Density of Mature } \\
\text { Woody Vegetation }\end{array}$ & 4.76 & 4.76 & 4.76 & - & 14.3 \\
\hline $\begin{array}{l}\text { Density of Old } \\
\text { Forest }\end{array}$ & 0 & 9.52 & 0 & - & 0 \\
\hline $\begin{array}{l}\text { Irregularity in } \\
\text { Vegetation Height }\end{array}$ & 9.52 & 14.3 & 19 & - & 4.76 \\
\hline $\begin{array}{l}\text { Vegetation Type } \\
\text { Distribution }\end{array}$ & 28.6 & 28.6 & 14.3 & - & 28.6 \\
\hline \multicolumn{7}{|c|}{ Satelite Image-derived } \\
\hline DVI & 0 & 13.3 & 33.3 & - & 0 \\
\hline GDVI & 6.67 & 0 & 20 & - & 6.67 \\
\hline GNDVI & 13.3 & 6.67 & 13.3 & - & 13.3 \\
\hline NDVI & 20 & 20 & 6.67 & - & 33.3 \\
\hline OSAVI & 33.3 & 33.3 & 26.7 & - & 26.7 \\
\hline SAVI & 26.7 & 26.7 & 0 & - & 20 \\
\hline
\end{tabular}

Table 6. Vegetation anomalies index in percentage for active landslide activity with different landslide type

According to Table 6, vegetation type distribution is the most important indicator of characterizing deep-seated active landslides. The vegetation type that contributes the highest percentage is grass because deep-seated landslide usually caused severe loss to the vegetation cover (Forbes and Broadhead, 2011). Canopy gap is the second most important indicator. This is proven by field validation data distinctly indicated the signature of canopy gap in the landslide area compared to the healthy forests and also parallel with the research by Gode and Razak (2013). Meanwhile, OSAVI with range from 0 to 0.25 is shown as the highest frequency of occurrence in the deep-seated active scenario for category satelite image-derived as it shows the bare-earth surface.

For shallow active landslides, the most importance indicator is presence of agriculture, followed by high density of shrub. Kundasang area specifically is well-known as the famous agriculture area of Malaysia. Therefore, the result obtained in this scenario will not be suitable for areas other than agriculture area. From the field observation, most of the shallow active landslide is usually being used as an agricultural site due to high nutrient content. This is because the soil has undergone a process of movement that has indirectly been undergoing soil cultivation process.

Vegetation anomalies index for rotational active landslide shows that high density of shrub is the most frequent vegetation anomaly. A rotational active landslide is happened with rotating type of motion in the soil movement. With a rapid movement of landslide in rotational-type of motion, it is hard for the woody vegetation to grow. DVI value with low vegetation index is shown as the most frequent vegetation index class in rotational active. This is because low DVI value indicates that low photosynthesis process has occurred.

Next, grass was shown as the most important indicator in characterizing complex active landslides. Complex active landslides happened when two (2) or more landslide types occurring in a landslide area. The presence of woody vegetation is the least important indicator that can be derived from complex active landslide area. NDVI with range from negative value to 0.1 indicates as the most importance characteristic of complex active landslides. This range is representing nearly non-vegetated area. Next, vegetation anomalies index for dormant landslide activity can be seen in Table 7 .

\begin{tabular}{|c|c|c|c|c|c|}
\hline \multirow{2}{*}{$\begin{array}{l}\text { Vegetation } \\
\text { Anomalies }\end{array}$} & \multicolumn{5}{|c|}{ Percentage of importance (\%) } \\
\hline & DS & $\mathbf{S}$ & $\mathbf{R}$ & $\mathbf{T}$ & $\mathbf{C}$ \\
\hline \multicolumn{6}{|c|}{ LiDAR-derived } \\
\hline Canopy Gap & 9.52 & 9.52 & 4.76 & 0 & - \\
\hline Density of Shrub & 0 & 0 & 9.52 & 23.8 & - \\
\hline $\begin{array}{l}\text { Density of Young } \\
\text { Woody Vegetation }\end{array}$ & 14.3 & 23.8 & 23.8 & 28.6 & - \\
\hline $\begin{array}{l}\text { Density of Mature } \\
\text { Woody Vegetation }\end{array}$ & 23.8 & 28.6 & 28.6 & 19 & - \\
\hline $\begin{array}{l}\text { Density of Old } \\
\text { Forest }\end{array}$ & 28.6 & 19 & 19 & 9.52 & - \\
\hline $\begin{array}{l}\text { Irregularity in } \\
\text { Vegetation Height }\end{array}$ & 4.76 & 4.76 & 0 & 14.3 & - \\
\hline $\begin{array}{l}\text { Vegetation Type } \\
\text { Distribution }\end{array}$ & 19 & 14.3 & 14.3 & 4.76 & - \\
\hline \multicolumn{6}{|c|}{ Satelite Image-derived } \\
\hline DVI & 20 & 20 & 20 & 33.3 & - \\
\hline GDVI & 26.7 & 26.7 & 26.7 & 26.7 & - \\
\hline GNDVI & 33.3 & 33.3 & 33.3 & 20 & - \\
\hline NDVI & 0 & 0 & 0 & 0 & - \\
\hline OSAVI & 6.67 & 6.67 & 6.67 & 6.67 & - \\
\hline SAVI & 13.3 & 13.3 & 13.3 & 13.3 & - \\
\hline
\end{tabular}

"DS = Deep Seated, $S=$ Shallow, $R=$ Rotational,

$T=$ Translational, and $C=$ Complex

Table 7. Vegetation anomalies index in percentage for dormant landslide activity with different landslide type

Based on Table 7, the most important bio-indicator for deepseated dormant is high density of old forest because in the dormant state, well-vegetated forest established. For shallow dormant landslides, high density of mature woody vegetation was the most important indicator as it gave $28.6 \%$. Meanwhile, density of shrub shows the least important indicator among the 
LiDAR-derived vegetation indicator. GNDVI shows the highest percentage for satellite-derived result due to high water uptake by the matured woody vegetation (Chan et al., 2013). NDVI shows the least significance parameters towards recognizing shallow dormant landslide areas.

Vegetation anomalies index for rotational dormant landslides shows that medium density of matured woody vegetation was the most important indicator while medium density of young woody vegetation is the second most important indicator. Same as other previously mentioned dormant-state landslides, GNDVI is shown as the most important indicator derived from satellite image data. For translational dormant landslides, high density of young woody vegetation was shown as the most important indicator for LiDAR-derived vegetation anomalies. Meanwhile, canopy gap is shown as the least important vegetation anomaly as the vegetation has been well-established. High value of DVI was shown as the most important vegetation anomaly derived from satellite image. High value of DVI means high photosynthesis activity occurred in translational dormant landslide. Next, vegetation anomalies index for relict landslide activity can be seen in Table 8 .

\begin{tabular}{|c|c|c|c|c|c|}
\hline \multirow{2}{*}{$\begin{array}{l}\text { Vegetation } \\
\text { Anomalies }\end{array}$} & \multicolumn{5}{|c|}{ Percentage of importance $(\%)$} \\
\hline & DS & $\mathbf{S}$ & $\mathbf{R}$ & $\mathbf{T}$ & $\mathbf{C}$ \\
\hline \multicolumn{6}{|c|}{ LiDAR-derived } \\
\hline Canopy Gap & 19 & 14.3 & - & 14.3 & - \\
\hline Density of Shrub & 9.52 & 0 & - & 4.76 & - \\
\hline $\begin{array}{l}\text { Density of Young } \\
\text { Woody Vegetation }\end{array}$ & 4.76 & 4.76 & - & 0 & - \\
\hline $\begin{array}{l}\text { Density of Mature } \\
\text { Woody Vegetation }\end{array}$ & 14.3 & 23.8 & - & 28.6 & - \\
\hline $\begin{array}{l}\text { Density of Old } \\
\text { Forest }\end{array}$ & 0 & 9.52 & - & 9.52 & - \\
\hline $\begin{array}{l}\text { Irregularity in } \\
\text { Vegetation Height }\end{array}$ & 23.8 & 28.6 & - & 23.8 & - \\
\hline $\begin{array}{l}\text { Vegetation Type } \\
\text { Distribution }\end{array}$ & 28.6 & 19 & - & 19 & - \\
\hline \multicolumn{6}{|c|}{ Satelite Image-derived } \\
\hline DVI & 33.3 & 26.7 & - & 26.7 & - \\
\hline GDVI & 26.7 & 20 & - & 20 & - \\
\hline GNDVI & 20 & 6.67 & - & 13.3 & - \\
\hline NDVI & 0 & 0 & - & 6.67 & - \\
\hline OSAVI & 13.3 & 13.3 & - & 0 & - \\
\hline SAVI & 6.67 & 33.3 & - & 33.3 & - \\
\hline
\end{tabular}

Table 8. Vegetation anomalies index in percentage for relict landslide activity with different landslide type

According to Table 8, most important indicator of deep-seated relict landslide is presence of secondary forest on the landslide area. However, due to minimal number of polygons in deepseated relict landslide scenario, the result obtained in this iteration is less accurate since density of old forest is the least important. Density of old forest should give high value and it is reflected in the observations during field visit.

Irregularity in vegetation height is shown as the most important indicator, while high density of mature woody vegetation is shown as the second most important indicator for shallow relict landslides. For satellite data source, SAVI with value of ranged 0.75 to 0.95 as the most important indicator. This range value is located on the matured woody vegetation area.

Medium density of mature woody vegetation was shown as the highest percentage of importance for translational relict, followed by irregularity in vegetation height as the second most important indicator. Again, SAVI as the most important indicator for translational relict landslides for satellite-image data derived.

\section{CONCLUSION AND DISCUSSIONS}

Analysing vegetation anomaly patterns using remotely sensed data is a new approach of mapping and analysing landslide activity based on different landslide type and depth. Previously, many studies that have been done in analysing landslide activity, especially based on interpretation of morphological and drainage pattern. However, different approach was taken in this study by focussing in the vegetation anomalies pattern. This study demonstrates a procedure in generating vegetation anomaly index library from remote sensing data that may be used in future as a landslide interpretation source. This procedure was done by characterizing the weight obtained from the landslide activity probability maps focussing on Kundasang, which had been struck by earthquake in June 2015. The performances of the landslide activity probability map generated using bivariate statistical approach were evaluated using success rate and prediction rate. The results revealed that vegetation anomalies as the indicator of analysing landslide activity is reliable as it gave average of $75 \%$ success rate value and $72 \%$ of the scenarios gave more than $50 \%$ prediction rate value. The results obtained vary across different landslide activity, type and depth.

\section{ACKNOWLEDGEMENTS}

We would like to express our gratitude to Minerals and Geoscience Department for the remote sensing data and experts in the landslides mapping and inventory process. Special thanks to the experts from various departments including Minerals and Geoscience Department, Public Works Department, PLAN@Malaysia, and Universiti Malaysia Sabah.

\section{REFERENCES}

Akgun, A., Dag, A., and Bulut, A., 2008. Landslide Susceptibility Mapping for a Landslideprone Area. Environmental Geology, 54(6), pp. 1127-1143

Ardizzone, F., Cardinali, M., Galli, M., Guzzetti, F., and Reichenbach, P., 2007. Identification and mapping of recent rainfall-induced landslides using elevation data collected by airborne Lidar. Natural Hazards and Earth System Science, 7(6), pp. 637-650.

Bai, S. B., Wang, J., Lü, G. N., Zhou, P. G., Hou, S. S., and Xu, S. N., 2010. GIS-based logistic regression for landslide susceptibility mapping of the Zhongxian segment in the Three Gorges area, China. Geomorphology, 115(1-2), pp. 23-31.

BeautifulKK. $2010 . \quad$ "Kundasang Town." http://beautifulkk.com/2008/06/06/kundasang. 
Bland, J. M., and Altman, D. G., 1996. Statistics notes: measurement error. Bmj, 313(7059), 744.

Chan, S., Rajat, B., Raymond, H., and Tom, J., 2013. Vegetation Water Content. NASA-Jet Propulsion Laboratory. Chen, Q., 2007. Airborne lidar data processing and information extraction. Photogrammetric engineering and remote sensing, 73(2), pp 109-112.

Choi, J., Oh, H. J., Lee, H. J., Lee, C., and Lee, S., 2012. Combining landslide susceptibility maps obtained from frequency ratio, logistic regression, and artificial neural network models using ASTER images and GIS. Engineering Geology, 124, pp. 12-23.

ClimateData.ORG. $2015 . \quad$ "Climate:Kundasang." 2016(1/4/2016). http://en.climate-data.org/location/703701/.

Constantin, M., Bednarik, M., Jurchescu, M. C., and Vlaicu, M., 2011. Landslide susceptibility assessment using the bivariate statistical analysis and the index of entropy in the Sibiciu Basin (Romania). Environmental earth sciences, 63(2), pp. 397-406.

Daily Express. 2015. "Mudslides Hit Kundasang, KB Villages." http://www.dailyexpress.com.my/news.cfm?NewsID=100647.

Eeckhaut, M., Poesen, J., Verstraeten, G., Vanacker, V., Nyssen, J., Moeyersons, J., and Vandekerckhove, L., 2007. Use of LIDAR-derived images for mapping old landslides under forest. Earth Surface Processes and Landforms, 32(5), pp. 754769.

Elvidge, C. D., and Chen, Z., 1995. Comparison of broad-band and narrow-band red and near-infrared vegetation indices. Remote sensing of environment, 54(1), pp. 38-48.

Fernández, T., Jiménez, J., Fernández, P., El Hamdouni, R., Cardenal, F. J., Delgado, J., and Chacón, J., 2008. Automatic detection of landslide features with remote sensing techniques in the Betic Cordilleras (Granada, Southern Spain). The International Archives of the Photogrammetry, Remote Sensing and Spatial Information Sciences, XXXVII. Part B, 8, pp. 351356.

Filippo, A S. 2005. "Pairwise Comparison." http://deseng.ryerson.ca/ fil/t/pwisecomp.html.

Ginzler, C., Bärtschi, H., Bedolla, A., Brassel, P., Hägeli, Hauser, M., Kamphues, H., Laranjeiro, L., Mathys, L., Uebersax, D., Weber, E., Wicki, P., and Zulliger, D., 2005. Luftbildinterpretation LFI3 - Interpretationsanleitung zum dritten Landesforestinventar. Eidgenössische Forschungsanstalt für Wald, Schnee und Landschaft WSL. Birmensdorf. 87

Glenn, N. F., Streutker, D. R., Chadwick, D. J., Thackray, G. D., and Dorsch, S. J., 2006. Analysis of LiDAR-derived topographic information for characterizing and differentiating landslide morphology and activity. Geomorphology, 73(1-2), pp. 131-148.

Guzzetti, F., Mondini, A. C., Cardinali, M., Fiorucci, F., Santangelo, M., and Chang, K. T., 2012. Landslide inventory maps: New tools for an old problem. Earth-Science Reviews, 112(1-2), pp. 42-66.

Haneberg, W. C., Cole, W. F., and Kasali, G., 2009. Highresolution lidar-based landslide hazard mapping and modeling,
UCSF Parnassus Campus, San Francisco, USA. Bulletin of Engineering Geology and the Environment, 68(2), pp. 263-276.

Harker, R. I., 1996. Curved tree trunks: indicators of soil creep and other phenomena. The Journal of Geology, 104(3), pp. 351358 .

Hede, A. N. H., Kashiwaya, K., Koike, K., and Sakurai, S., 2015. A new vegetation index for detecting vegetation anomalies due to mineral deposits with application to a tropical forest area. Remote Sensing of Environment, 171, pp. 83-97. Huete, A. R., 1988. A soil-adjusted vegetation index (SAVI). Remote sensing of environment, 25(3), pp. 295-309.

Henderson, G.R. \& Preston, P.T. 1977. Fodder farming in Kenya. East African Literature Bureau, Nairobi. pp. 149.

Hupp, C. R., 1983. Seedling establishment on a landslide site. Castanea, pp. 89-98.

Hutchinson, J. N., 1994. Some aspects of the morphological and geotechnical parameters of landslides, with examples drawn from Italy and elsewhere. Geologica Romana, 30, pp. 1-14.

Ismayatim, Wan Faizal. 2015. "Rumah Terjunam Sungai Akibat Tanah Runtuh Di Mesilau.” Berita Harian.

Jaboyedoff, M., Oppikofer, T., Abellán, A., Derron, M. H., Loye, A., Metzger, R., and Pedrazzini, A., 2012. Use of LIDAR in landslide investigations: a review. Natural hazards, 61(1), pp. 5-28.

Jamaludin, S., and Hussein, A. N., 2006. Landslide hazard and risk assessment: The Malaysian experience. Notes.

Lee, S., 2007. Application and verification of fuzzy algebraic operators to landslide susceptibility mapping. Environmental Geology, 52(4), pp. 615-623.

Lee, S., 2005. Application of logistic regression model and its validation for landslide susceptibility mapping using GIS and remote sensing data. International Journal of Remote Sensing, 26(7), pp. 1477-1491.

Lin, W. T., Lin, C. Y., and Chou, W. C., 2006. Assessment of vegetation recovery and soil erosion at landslides caused by a catastrophic earthquake: a case study in Central Taiwan. Ecological Engineering, 28(1), pp. 79-89.

Mackey, B. H., and Roering, J. J., 2011. Sediment yield, spatial characteristics, and the long-term evolution of active earthflows determined from airborne LiDAR and historical aerial photographs, Eel River, California. Bulletin, 123(7-8), pp. 15601576.

McKean, J., and Roering, J., 2004. Objective landslide detection and surface morphology mapping using high-resolution airborne laser altimetry. Geomorphology, 57(3-4), 331-351.

Moos, C., 2014. How Does Forest Structure Affect Landslide Susceptibility? Statistical Prediction Models for Shallow Landslides Integrating Forest Structure (Doctoral dissertation, Master Thesis. ETH Zurich).

Orodho, A. B., 2006. The role and importance of Napier grass in the smallholder dairy industry in Kenya. Food and Agriculture Organization, Rome Retrieved August, 24, 2011. 
Parise, M., 2003. Observation of surface features on an active landslide, and implications for understanding its history of movement. Natural Hazards and Earth System Science, 3(6), pp. 569-580.

Pradhan, B., Sezer, E. A., Gokceoglu, C., and Buchroithner, M. F., 2010. Landslide susceptibility mapping by neuro-fuzzy approach in a landslide-prone area (Cameron Highlands, Malaysia). IEEE Transactions on Geoscience and Remote Sensing, 48(12), pp. 4164-4177.

Rahman, M. Z. A., and Gorte, B. G. H., 2009. Tree crown delineation from high resolution airborne lidar based on densities of high points. In Proceedings ISPRS Workshop Laserscanning 2009, September 1-2, France, IAPRS, XXXVIII (3/W8), 2009. ISPRS.

Razak, K. A., Bucksch, A., Damen, M., van Westen, C., Straatsma, M., and de Jong, S., 2013a. Characterizing tree growth anomaly induced by landslides using LiDAR. In Landslide science and practice pp. 235-241. Springer, Berlin, Heidelberg.

Razak, K. A., Bucksch, A., Straatsma, M., Van Westen, C. J., Bakar, R. A., and De Jong, S. M. 2013b. High density airborne LIDAR estimation of disrupted trees induced by landslides. In Geoscience and Remote Sensing Symposium (IGARSS), 2013 IEEE International (pp. 2617-2620). IEEE.

Razak, K. A., 2014. Airborne laser scanning for forested landslides investigation in temperate and tropical environments. Enschede, The Netherlands.

Reis, S., 2008. Analyzing land use/land cover changes using remote sensing and GIS in Rize, North-East Turkey. Sensors, 8(10), pp. 6188-6202.

Rice University., 2016. "Reading, Analysing and Interpreting Vertical Aerial Photos and Orthphoto Maps." https://cnx.org/contents/5dSSFw9j@1/Reading-analysing-andinterpre.

Ritter, J., and Eng, P., 2012. Soil erosion-causes and effects. Ontario Ministry of Agriculture and Rural Affairs, pp. 12-105.

Rondeaux, G., Steven, M., and Baret, F., 1996. Optimization of soil-adjusted vegetation indices. Remote sensing of environment, 55(2), pp. 95-107.

Schulz, W. H., 2007. Landslide susceptibility revealed by LIDAR imagery and historical records, Seattle, Washington. Engineering Geology, 89(1-2), pp. 67-87.

Smith, J., 1987a. Close range photogrammetry for analyzing distressed trees. Photogrammetria, 42(1), pp. 47-56.

Soeters, R, and C J van Westen. 1996. "Slope Instability Recognition, Analysis, and Zonation." In Landslides, Investigation and Mitigation (Transportation Research Board, National Research Council, Special Report; 247).

Sripada, R. P., Heiniger, R. W., White, J. G., and Meijer, A. D., 2006. Aerial Color Infrared Photography for Determining Early In-Season Nitrogen Requirements in Corn This project was supported in part by Initiative for Future Agriculture and Food Systems Grant no. 00-52103-9644 from the USDA Cooperative State Research, Education, and Extension Service. Agronomy Journal, 98(4), pp. 968-977.
The Borneo Post. 2015. "6.0 Trembler Rattles Sabah West Coast."

The Information Technology, Telecommunications and Multimedia Industry Standards Committee. 2004. "MS 1759:2004."

Tongkul, F., 1987. Sedimentology and structure of the Crocker Formation in the Kota Kinabalu Area, Sabah, East Malaysia (Doctoral dissertation, Royal Holloway, University of London).

Tongkul, Felix. 2015. "Sabah Quake: A Geologist's Perspective.” The Star.

Tucker, C. J., 1979. Red and photographic infrared linear combinations for monitoring vegetation. Remote sensing of Environment, 8(2), pp. 127-150.

United States Geological Survey. 2015. M6.0 - 12km WNW of Ranau, Malaysia.

UTM PBRC. 2016. Inception Report.

Varnes, D. J., 1958. Landslide types and processes. Landslides and engineering practice, 29(3), pp. 20-45.

Van Westen, C., 2003. Mapping Landslides from Airphotos.

Veblen, T. T., and Ashton, D. H., (1978). Catastrophic influences on the vegetation of the Valdivian Andes, Chile. Vegetatio, 36(3), pp. 149-167.

Watkins, A., and Hughes, S., 2012. Landslides, Slope Failure, and Other Mass Wasting Processes. Retrieved on 3 March 2012, from http://wapi.isu.edu/envgeo/EG4_mass_wasting/ EG_module_4.htm.

Wikipedia., 2015a. 2015 Sabah Earthquake. Available: https://en.wikipedia.org/wiki/2015_Sabah_earthquake.

Wikipedia., 2015b. Pairwise Comparison. Available: https://en.wikipedia.org/wiki/Pairwise_comparison.

Wikipedia., 2017. Standard Deviation. Available: https://en.wikipedia.org/wiki/Standard_deviation\#cite_noteStatNotes-1.

Wikitravel., 2015. Kundasang. Available: http://wikitravel.org/en/Kundasang.

Wills, C. J., and McCrink, T. P., 2002. Comparing landslide inventories: The map depends on the method. Environmental \& Engineering Geoscience, 8(4), pp. 279-293.

Willhauck, G., Schneider, T., De Kok, R., and Ammer, U., 2000, July. Comparison of object oriented classification techniques and standard image analysis for the use of change detection between SPOT multispectral satellite images and aerial photos. In Proceedings of XIX ISPRS congress, 33, pp. 35-42).

Revised August 2018 